\title{
THE FIRST DATING OF CAVE ICE FROM THE TATRA MOUNTAINS, POLAND AND ITS IMPLICATION TO PALAEOCLIMATE RECONSTRUCTIONS
}

\author{
HELENA HERCMAN ${ }^{1}$, MICHAL GĄSIOROWSKI ${ }^{1}$, MICHAL GRADZIŃSKI ${ }^{2}$ \\ and DITTA KICIŃSKA ${ }^{3}$ \\ ${ }^{1}$ Institute of Geological Sciences, Polish Academy of Sciences, Research Centre in Warsaw, \\ Twarda 51/55, 00-818 Warszawa, Poland \\ ${ }^{2}$ Institute of Geological Sciences, Jagiellonian University, \\ Oleandry 2a, 30-063 Kraków, Poland \\ ${ }^{3}$ Institute of Geology, Adam Mickiewicz University, \\ Maków Polnych 16, 61-606 Poznań, Poland
}

Received 7 April 2010

Accepted 26 July 2010

\begin{abstract}
Lodowa Cave in Ciemniak, which belongs to the dynamic ice cave type, contains the biggest perennial block of cave-ice in the Tatra Mountains. The ice represents congelation type, since it originates from freezing of water which infiltrates the cave. Two generations of ice have been recognized in this cave. They are divided by the distinct unconformity. The ice building both generations is layered. Two moths which were found in the younger generations were sampled and dated by ${ }^{14} \mathrm{C}$ method yielding $195 \pm 30$ and $125 \pm 30$ years. Bearing in mind the position in the section and the fact that the cave ice has waned since the 20 s of the last century, the age is 1720-1820 AD and 1660-1790 $\mathrm{AD}$ respectively. It proves that the ice was formed during the Little Ice Age. Hence, the erosion boundary which underlies this generation records the degradation of ice before the Little Ice Age most probably during the Medieval Warm Period. The ice volume in the cave was substantially smaller before the Little Ice Age than it is today, despite the clear tendency to melting, which has been recognized since 20 s of the last century. The older generation of ice is supposed to have its origins in a cold stage between the Atlantic period and the Medieval Warm Period.
\end{abstract}

Keywords: Little Ice Age, ${ }^{14} \mathrm{C}$ dating, cave moths, Western Carpathians.

\section{INTRODUCTION}

Various cave deposits have been studied as palaeoclimatic archive for a long time. Although cave ice provides a unique record in non-glaciated mid-latitude regions, it has been only recently regarded as useful palaeoclimatic proxy. Since it is characterized by a relatively high rate of growth, reaching up to several centimetres per year, it offers a high resolution record. It is of definitely higher resolution than that yielded by carbonate speleothems which are studied extensively in palaeoclimatic studies. On the other hand, cave ice sections span rather short periods of geological past and are susceptible

Corresponding author: H. Hercman

e-mail: hhercman@twarda.pan.pl to postedpositional changes, for instance ablation, selective melting and refreezing. Moreover, the origin of cave ice may be governed not only by regional climate but also by a wide range of local agents influencing the microclimatic condition of a particular cave. Furthermore, cave ice originates in different ways. The most popular are those formed due to: (i) regelation of snow, (ii) freezing of percolation water, and (iii) freezing of water vapour which condenses on cave walls (Yonge, 2004; Ford and Williams, 2007). They are called glaciére, congelation ice and hoarfrost, respectively. Each of the aforementioned ice types is formed in different topographic/microclimatic conditions and builds different accumulations. It is also characterized by different microstructure and isotopic composition (see Lauriol and Clark, 1993; Yonge and MacDonald, 1999). Hence, considerable caution must be exercised while interpreting the origin of cave ice sec- 
tions and drawing conclusions on palaeoclimatic conditions based on these interpretations. Nevertheless, the cave ice sections are very useful in unravelling the past climate changes, even so subtle as North Atlantic Oscillations (Stoffel et al., 2009).

Carrying out the palaeoclimatic study based on cave ice records demands setting up of robust chronology, which in turn strongly depends on precise dating of cave ice sections. In fact, there is a scarcity of precisely dated cave ice sections. Their number is several orders of magnitude smaller than the number of other cave deposits that have been dated.

Several methods may be applied to date cave ice sections. The more obvious is the counting of layers; however, careful observations suggest that ice layers can be not annual, ice sections may contain several hiatuses and amalgamation horizons (Fórizs et al., 2004; Holmlund et al., 2005). It results from periodic negative mass balance of ice (Luetscher et al., 2007). Isotopic methods, for instance ${ }^{210} \mathrm{~Pb}$, tritium and ${ }^{14} \mathrm{C}$, may be also used to date cave ice. Each of them has its own limitations. Tritium and ${ }^{210} \mathrm{~Pb}$ have a very short range. The latter method can be affected by impurities in the ice (Leutscher et al., 2007). Wilson (1998), based on his study in lava tubes in Candelaria Ice Cave, claims that ${ }^{14} \mathrm{C}$ dating of $\mathrm{CO}_{2}$ trapped within cave ice yielded reliable effects. However, his samples were collected in a lava-tube cave, where atmospheric and biogenic carbon are not mixed with dead-carbon derived from carbonate host rock. In the case of carbonate karst the admixture of dead-carbon can significantly affect the ${ }^{14} \mathrm{C}$ dating, which may be an important constraint on the possibility of ${ }^{14} \mathrm{C}$ dating of cave ice. Moreover, Fórizs et al. (2004) and Leutscher et al. (2007) point at possible selective melting and refreezing of cave ice, which, of course, can influence the dating results obtained by all the above mentioned isotope methods.

Cave-ice quite commonly contains various organic debris which is incorporated during its growth. The ${ }^{14} \mathrm{C}$ dating of organic impurities entrapped within cave ice seems to be a relatively profitable method. Some organic fragments, which are of external origin, passively enter the cave through big, vertical shafts. The tree trunks and branches found in Ghețarul de la Scărişoara and Gheţarul de la Focul Viu (both in Romania), ice caves in the Jura Mountains as well as and Eisgruben-Eishöhle can serve as examples. Others are skeletons, whole bodies, faecal pellets, feathers or nests of animals at least periodically inhabiting caves (Lauriol et al., 1988; Lauriol and Clark, 1993; Wilson, 1998; Yonge and MacDonald, 1999; Clausen et al., 2007). Such animal remains are perfectly preserved in below-zero temperatures and incorporated in cave ice.

To the best of the authors' knowledge, between 20 and 30 radiocarbon dates of organic material entrapped in cave ice have been published so far. The age of cave ice, based on such dating was established in the Southern Canadian Rocky Mountains (Yonge and MacDonald, 1999), the Mackenzie Mountains (Scotter and Simmons, 1976; Schroeder, 1977), northern Yukon (Lauriol et al., 1988; 2001; Lauriol and Clark, 1993), western United States (Wilson, 1998), the Austrian and Swiss Alps (Leutscher et al., 2005, 2007; Stoffel et al., 2009 and
Alcheitner, 1995; Pavuza and Spötl, 2000; Audra and Pavuza, 2004, respectively), as well as in the Romanian Carpathians (Silvestru, 1999; Racoviţă \& Onac, 2000; Fórizs et al., 2004; Kern et al., 2004; Holmlund et al., 2005). The only one ${ }^{14} \mathrm{C}$ date of organic remnants entrapped in cave ice from the Western Carpathians was published by Clausen et al. (2007) from Dobšiná Ice Cave. The majority of the above mentioned dates refer to plant fragments found just below vertical cave entrances within glaciére. The other samples, those found in cave interiors within congelation ice, were dated less frequently because of their general scarcity. They are limited mostly to high-latitude regions.

The main aim of this paper is to present dating results of organic fragments extracted from congelation ice in Lodowa Cave in Ciemniak (Jaskinia Lodowa w Ciemni$\mathrm{aku}$ ), which are the first dating results of such samples from the Tatra Mountains and the second from the Western Carpathians. The paper focuses also on the preliminary interpretation of history of the ice block in this cave as well as the impact of climatic changes on its development.

\section{SPELEOLOGICAL SETTING}

Lodowa Cave in Ciemniak is the biggest ice-cave in the Tatra Mountains (Siarzewski, 1994a, b). Its entrance is located at an altitude of $1715 \mathrm{~m}$ in the western slopes of Ciemniak mount above the timberline which is situated approximately at an altitude around $1500 \mathrm{~m}$ (Fig. 1). The rocky slope near and over the cave is covered with a high-mountain meadow accompanied by some clumps of mountain pine. The mean annual temperature in that altitudinal zone falls between 0 and $2^{\circ} \mathrm{C}$, while the mean annual precipitation exceeds $1800 \mathrm{~mm}$ (Hess, 1996).

The cave is $390 \mathrm{~m}$ in length and its vertical extent reaches $42 \mathrm{~m}$ (Fig. 2). Its entrance faces the north-west. The cave consists of a spacious main passage trending $\mathrm{W}-\mathrm{E}$ and two off-passages leading to the north. The main passage shows a zig-zag profile, it goes up from the entrance and then descends to the level $-10 \mathrm{~m}$ below the

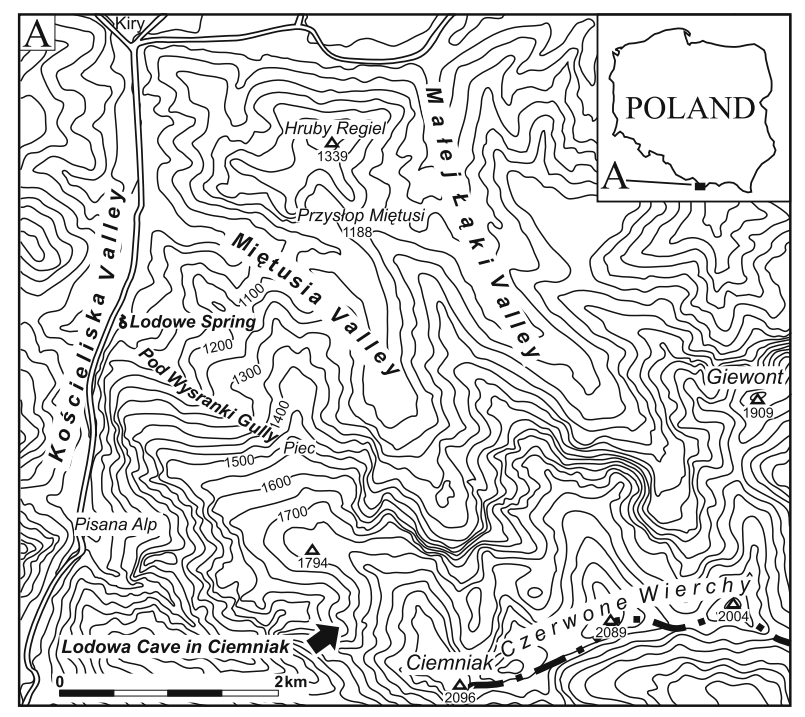

Fig. 1. Location of Lodowa Cave in Ciemniak 


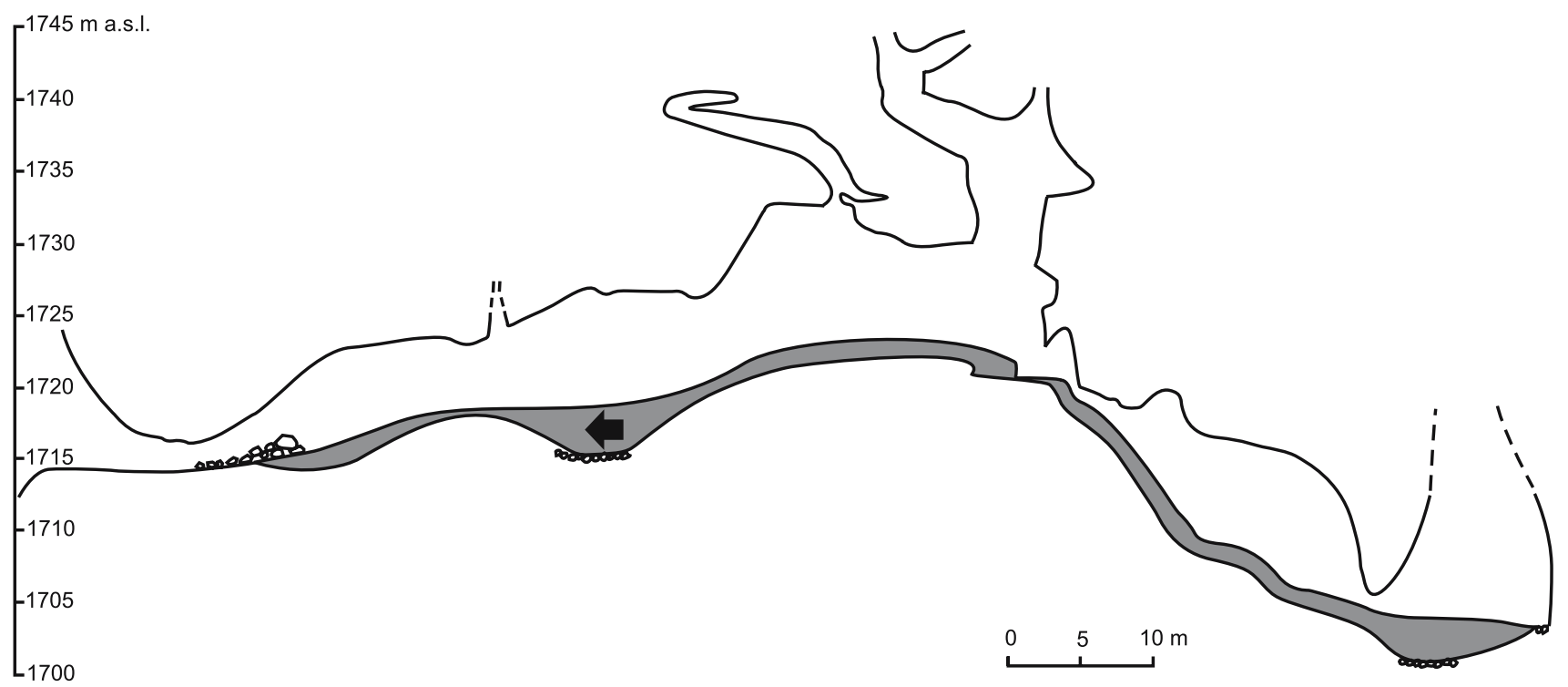

Fig. 2. Cross-section of Lodowa Cave in Ciemniak after Rygielski et al. (1995) modified, position of studied ice-section is arrowed.

entrance. The cave is developed in the Upper JurassicLower Cretaceous thick bedded limestones, the so-called "Malmo-Neocomian limestones". The limestones in which the cave originated belong to the tectonic autochthonous unit lying directly on the Tatra Mountains crystalline core. The cave passages are guided by inclined bedding planes and tectonic fissures trending N-S.

The cave represents a dynamic type. Relatively warm cave air escapes in cold seasons through chimneys and fissures developed in the cave ceiling. It is compensated by sucking of cold air from the outside through the cave entrance. Such a circulation type commences in late September (Rygielski et al., 1995). It results in freezing of cave interior. After the exchange of circulation in early June, the relatively warmer air from outside descends through the chimneys and fissures and pushes out the colder cave air. However, the ice melting process slows down the increase of internal temperature (Rachlewicz and Szczuciński, 2004).

Lodowa Cave in Ciemniak hosts an extensive mass of subterranean ice the volume of which is estimated as exceeding considerably $1500 \mathrm{~m}^{3}$ (Rachlewicz and Szczuciński, 2004). The ice covers the bottom of the main passage and forms some icefalls. It represents congelation type, since it originates from freezing of water which infiltrates the cave (Siarzewski, 1994a, b). Its thickness in the $90 \mathrm{~s}$ of the last century reached $5 \mathrm{~m}$, and was probably 2-4 $\mathrm{m}$ larger in the 20s (Rygielski et al., 1995).

The ice forms every late winter-early spring when the cave interior is below-zero zone but water from thawing snow can easily enter the cave by vertical fissures and chimneys in its ceiling. Conversely, the ice is degraded in summer due to warming up of the cave atmosphere and in winter due to loss by sublimation (Rachlewicz and Szczuciński, 2004). In summer and autumn water flows in a thin sheet over the ice surface. Locally, thermoerosional channels up to $50 \mathrm{~cm}$ wide and $20 \mathrm{~cm}$ deep are formed (Rachlewicz and Szczuciński, 2004). Hence, the ice mass balance is a net result of aggradation and degra- dation processes year round. The observation carried out since 20 s of the last century shows that ice volume has fluctuated, which influenced the cave morphology. The access to the lowermost part was periodically sealed by ice as it happened between 1987 and 1990 (Siarzewski, 1994a). Nevertheless, Siarzewski (1994a, b) and Rygielski et al. (1995) stress that the ice has displayed the general tendency to wane since the 20 s of the last century. This process substantially accelerated in the last two decades when on the average $30 \mathrm{~m}^{3}$ of ice melted out yearly according to the calculation by Rachlewicz and Szczuciński (2004). Recently, the ice level has lowered and the ice-bottom of the cave main passage has flattened.

The majority of authors describing the Lodowa Cave in Ciemniak deal with the origin of the ice cover and its connection with modern climatic regime of the cave. Little has been known about the age of the ice filling. Wójcik (1968) hypothesizes that the ice was formed in late Holocene after the climate optimum. Rygielski et al. (1995), based on findings of cereal pollens in ice samples, suggest that the cave was iced in historical times.

\section{MATERIALS AND METHOD}

The studied section is located in Chamber beneath Ice (Komora pod Lodem) which constitutes a rimaye between the ice block and the cave wall (Fig. 2). The exposed ice section has been carefully examined in order to find any organic particles entrapped within the ice body. Two moths were found and precisely located in the section. They were labeled as LOD 3 and LOD 4. The moths were carefully extracted from the ice by a geological hammer and chisel, put in plastic containers and immediately transported into the laboratory, where they were allowed to air-dry.

Radiocarbon dating has been performed in Poznań Radiocarbon Laboratory using AMS technique (Goslar et al., 2004). The ${ }^{14} \mathrm{C}$ concentration of the samples was measured using "Compact Carbon AMS" spectrometer 
produced by National Electrostatics Corporation, USA. Standard sample pretreatment procedure was used (Czernik and Goslar, 2001). Quoted errors are 1 standard deviation and the age is conventional radiocarbon age. The obtained dates have been calibrated using OxCal v. 3.10 (Bronk Ramsey, 1995, 2001) with calibration curve for atmospheric data from Reimer et al. (2004). Stratigraphic position of the studied samples in the ice profile has been taken into account using the option "sequence model".

\section{RESULTS}

The studied ice section reaches a maximal thickness of $2.6 \mathrm{~m}$ (Fig. 3). It displays distinct layering (Figs. 4, 5). The thickness of particular layers ranges from $2 \mathrm{~cm}$ to $14 \mathrm{~cm}$. They are transparent, deep blue in colour or opaque, and whitish in colour. Some layers, which are characterized by pale yellow colour, contain notable admixtures of calcite silt (Fig. 5). The basal layers of the ice cement limestone blocks constituting a bottom of the cave and follow its topography.

The section of cave ice reveals its two generations (see also Celejowska et al., 2007). They are divided by the distinctive unconformity inclined towards the cave entrance (Fig. 5). The older generation is being onlaped by the younger one. The older generation of ice reveals traces of destruction, most probably due to melting which preceded growth of the youngest generation. The dip of the unconformity surface varies between $15^{\circ}$ and $90^{\circ}$. It caused that the older generation crops out exclusively in eastern part of the section and pinches westwards. The older generation comprises layers more transparent and thicker while the ice forming the younger generation is predominantly opaque and thin-layered. A group of ice stalagmites incorporated into the older generation is visible through the transparent ice. The younger generation displays horizontal layering (Fig. 3). The textural difference between two ice generations suggests different con-

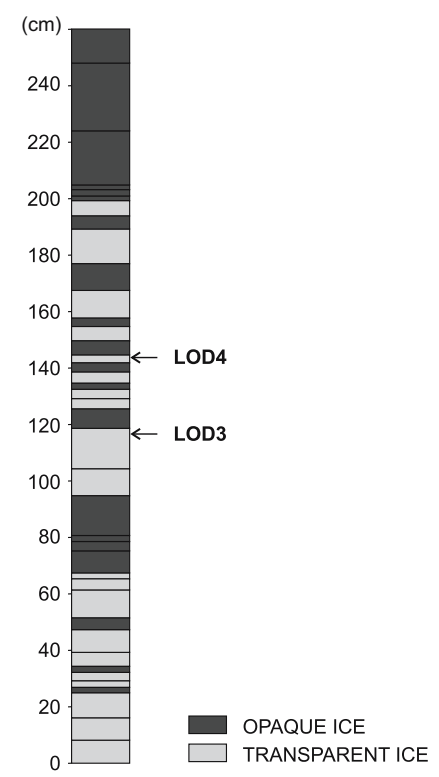

Fig. 3. Studied section of cave ice with position of sampled moths ditions of their origin, for example different temperature influencing different growth rate of ice crystals (cf. Racoviţă \& Onac, 2000).

The two moths were situated in layered ice, probably in the lower or middle part of the section where ice layers were counted by Zwoliński (1951) and Rygielski (1995). They were aligned subparallelly to the ice layering (Fig. 6). The LOD 3 moth occurred just below ice wall and partly emerged from it. The LOD 4 moth was situated ca. $2.5 \mathrm{~cm}$ inside the ice wall. Most probably they represent Triphosa dubitata species, which recently has also been detected in the cave (Kowalski, 1955). Rela-

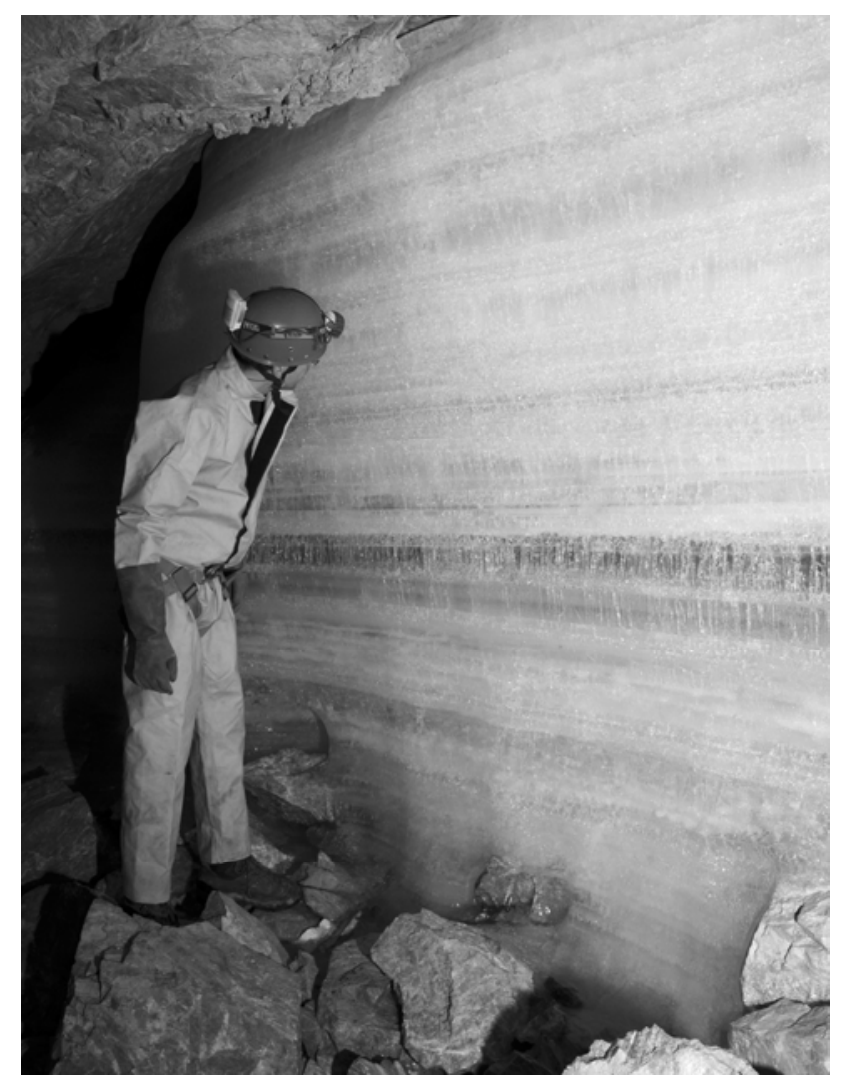

Fig. 4. Studied ice section, distinct layering of ice is clearly visible.

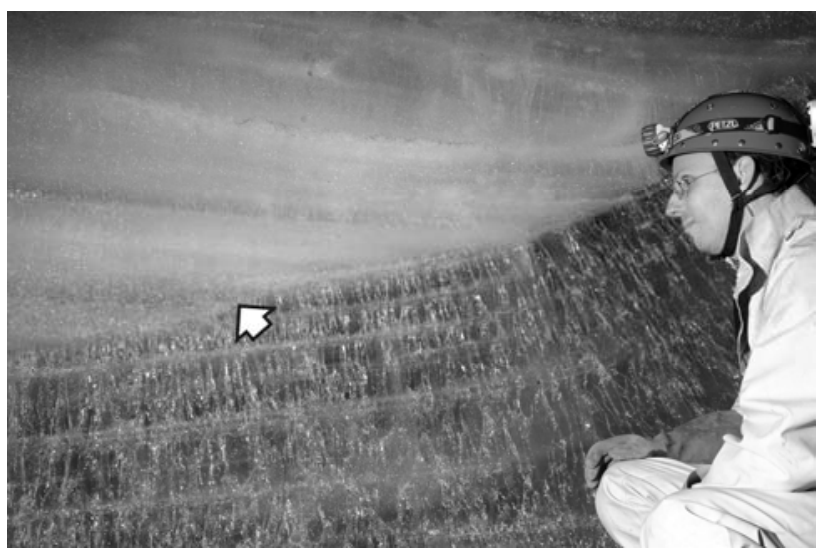

Fig. 5. Unconformity surface between two ice generations, younger generation contains layers with notable admixtures of calcite silt, traces of thermo-erosion are visible beneath unconformity surface (arrow). 


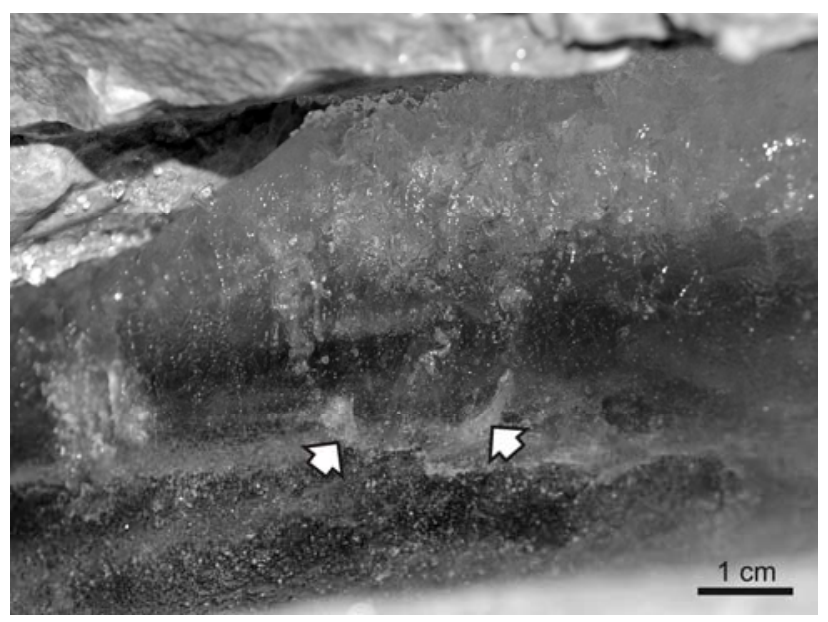

Fig. 6. Moth (labeled as LOD 4) completely entrapped within layered ice of younger generation (arrows).

tively good preservation of fragile moth tissues proves that they are isochronous with the cave ice.

Radiocarbon analyses as well as calibration results are given in Table 1 and Fig. 7. Calibrated ages are presented as $2 \sigma$ ranges from sequence model. The age of older sample LOD 3 (Poz-33194) is between 290 cal BP and $170 \mathrm{cal}$ BP or between 150 cal BP and 20 cal BP. The younger one age, LOD 4 (Poz-33195) is between 230 cal BP and 130 cal BP or 40 cal BP and -10 cal BP.

\section{DISCUSSION}

More precise age estimation of the upper ice generation is possible bearing in mind constant tendency of the ice block to melt since 1922 when the scientific observation in the cave commenced (Siarzewski, 1994a, b; Rygielski et al., 1995). Detailed geodetic survey and analyses of published data allowed Rachlewicz and Szczuciński (2004) to calculate the ice decrease between 1922 and 2004 at $2000 \mathrm{~m}^{3}$. Zwoliński (1951) mentions that in 1933

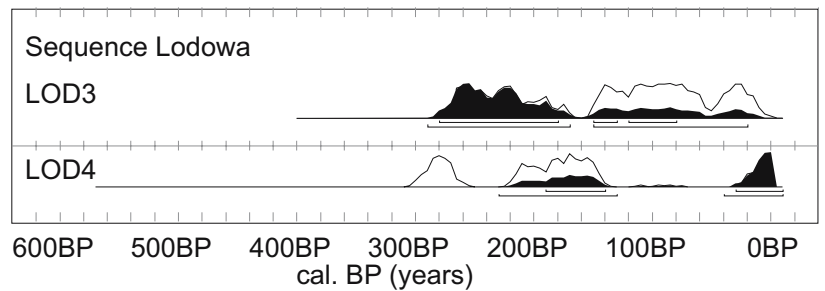

Fig. 7. Radiocarbon data calibration results using sequence model; black coloured distributions take into account positions of analyzed samples in ice section. minimal thickness of ice section in the Chamber beneath Ice was $5 \mathrm{~m}$. The section studied presently reaches $2.6 \mathrm{~m}$. It implies that more than $2 \mathrm{~m}$ of ice melted out. Taking this into account, one may presume that the ice hosting moths must be considerably older than 1920 AD. Hence, it is possible to use the constraint $1920 \mathrm{AD}$ for radiocarbon data calibration (Table 1, Fig. 8). Since the age 1830-1880 AD and 1910-1920 AD of the LOD 4 sample has only $6.8 \%$ probability, one may accept that the sample in question is from the period 1720-1820 AD. The older sample (LOD 3) is most probably from 1660-1790 $\mathrm{AD}$ period. The above results are in line with the opinion by Rygielski et al. (1995) about relatively young age of the discussed cave-ice. They postulated, based on finding of cereal pollen in cave-ice samples that it grew synchronously with human inhabitation of the peri-Tatric region.

From the methodic point of view the obtained results show that even dead-bodies of small cave creatures can be useful in dating cave ice by ${ }^{14} \mathrm{C}$ method. The above method has been mainly applied to coarse plant debris or mammal skeletons so far. Hence, it can widen the possibility of application of this method to date cave ice in zones located far from entrances. In these zones there is a scarcity of plant debris abounding mainly in twilight zones below vertical cave entrances.

Lodowa Cave in Ciemniak has dynamic air circulation and therefore its environment reacts intensively to surface climate conditions. The switch from positive to negative net effect in ice mass balance depends on both winter and summer temperature. Microclimatic monitoring suggests that for ice accumulation the best period is late winter and spring (Siarzewski, 1994a; Rygielski et al., 1995; Rachlewicz and Szczuciński, 2004), when the cave is invaded by a lot of water from snow melting and spring rains. Then, the water meets the temperature inside being still significantly below freezing point $\left(-7\right.$ to $\left.-2^{\circ} \mathrm{C}\right)$. On the other hand, harsh winters and warm summers are a time of intensive erosion of ice body - the former result

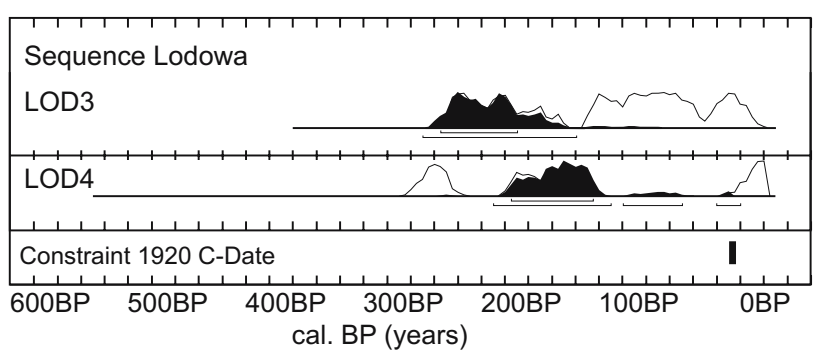

Fig. 8. Radiocarbon data calibration using sequence model with the constrain $1920 \mathrm{AD}$; black coloured distributions take into account positions of analyzed samples in ice section and constraint $1920 \mathrm{AD}$.

Table 1. Dating and calibration results

\begin{tabular}{lllcc}
\hline Sample & Lab. No. & Radiocarbon age & $\begin{array}{c}\text { Calibrated age } \\
(\mathbf{2} \boldsymbol{\sigma} \text { range for sequence model })\end{array}$ & Calibrated age assuming 1920 AD constraint \\
\hline LOD 3 & Poz-33194 & $125 \pm 30 \mathrm{BP}$ & $290 \mathrm{BP}(67.2 \%)$ 170BP & $1660 \mathrm{AD}(95.4 \%)$ 1790AD \\
& & & $150 \mathrm{BP}(28.2 \%)$ 20BP & $1720 \mathrm{AD}(88.6 \%) 1820 \mathrm{AD}$ \\
LOD 4 & Poz-33195 & $195 \pm 30 \mathrm{BP}$ & $230 \mathrm{BP}(47.4 \%) 130 \mathrm{BP}$ & $1830 \mathrm{AD}(5.5 \%) 1880 \mathrm{AD}$ \\
& & & $40 \mathrm{BP}(48.0 \%)-11 \mathrm{BP}$ & $1910 \mathrm{AD}(1.3 \%) 1920 \mathrm{AD}$ \\
\hline
\end{tabular}


in ice sublimation while the second in ice melting. It is contrary to static ice caves whose mass balance is governed predominantly by winter conditions (Luetscher et al., 2005; see also Silvestru, 1999). Hence, changes of ice mass balance in Lodowa Cave in Ciemniak can be used to reconstruct both the summer and winter climate conditions in the cave surroundings.

At least two generation of ice separated by distinct unconformity were identified. Radiocarbon age of the moths dates the middle part of the younger generation of ice at 1660-1820. This time period can be easily related to the Little Ice Age (LIA). This climatic event was identified also in lacustrine records from nearby Smreczyński Staw lake (Gąsiorowski and Sienkiewicz, 2010a) and from other lake sites in the Tatra Mountains (Kotarba, 2006; Gąsiorowski and Sienkiewicz, 2010b and references quoted herein). The LIA extended in the Tatra Mountains between the half of $14^{\text {th }}$ century and the end of $19^{\text {th }}$ century. The palaeolimnological data suggest that the first part of this period (around AD 1350 to AD 1550) was cold but dry and the second part (AD 1550 - AD 1900) was cold and relatively humid. Particularly, the first half of $19^{\text {th }}$ century was a time of intensive precipitation (Kotarba, 2006; Gąsiorowski and Sienkiewicz, 2010a). Dendrochronological reconstructions prove that this period abounds in several years with cold summers (Bednarz, 1984; Niedźwiedź, 2004). Bearing in mind the yearly dynamic of the discussed cave-ice it seems very plausible that the climate of the second part of the LIA, with heavy snowfalls during winters and short, cool summers, supported ice accumulation in the cave.

The erosion boundary between two generations of ice records the episode of intensive melting. It is located much further from the cave entrance than present ice front. It implies that the ice volume before the LIA was less than at present after almost a 70 year period of melting. The palaeolimnological data from the Tatra region prove that the LIA was preceded by a period of mild climate called the Medieval Warm Period (MWP). The MWP was warm and dry according to lacustrine records (Gąsiorowski and Sienkiewicz, 2010b) and was much longer than 20th century - the mild climate in the Tatra Mountains continued from 6 th till 14 th century. Hence, it is considered to be a likely period of the ice degradation which is recorded as the discussed erosion boundary.

The age of the ice older generation still remains an open question. The ice was probably equal or even greater in mass and extent than the LIA-ice. Therefore, it should be accumulated during a respectively long phase of cool and humid climate. Some palaeolimnological data suggest that the phase before $6^{\text {th }}$ century was relatively cold in the Tatra Mountains (Gąsiorowski and Sienkiewicz, 2010a). However, it is still little known about magnitude and time extent of this cooling. The lack of organic remains makes the ${ }^{14} \mathrm{C}$ dating impossible. However, if the constant degradation of ice in the cave continues the finding of material suitable for dating seems to be feasible.

The palaeontological findings can shed some light on the age of the older generation of ice. Wójcik (1968) reports the bones of Myotis bechsteinii bat from an offpassage in Lodowa Cave in Ciemniak. This species repre- sents thermophilous tree-dwellers (Dietz and Pir, 2009). It presently does not occur in the Tatra Mountains, however, it was quite abundant during the Atlantic period (Wołoszyn, 1996). Hence, one can suppose that during the Atlantic period the cave microclimatic conditions were suitable for this species. This, in turn, strongly suggests that the cave was ice-free at that time.

The postulated young age of the studied cave ice proves that Lodowa Cave in Ciemniak was at least once devoid of ice in the postglacial period similarly to several ice-caves in Europe and North America (e.g., Marshall and Brown, 1974; Achleitner, 1995; Pavuza and Spötl, 2000; Leutscher et al., 2005). Even the ice-plugs in the caves located near the Arctic Circle in Yukon territory were substantially smaller during the early Holocene than they are presently (Lauriol et al., 2001). On the other hand, distinct corrosion boundary below the LIA-ice implies that some ice survived the MWP, which is also the case in many European and American caves (Achleitner, 1995; Wilson, 1998).

Published data imply that the cave-ice originated during the LIA occurs also in many European caves, for instance in Focul Viu Ice Cave (Fórizs et al., 2004; Kern et al., 2004), Scărişoara Ice Cave (Silvestru, 1999; Holmlund, 2005), Dobšiná Ice Cave (Clausen et al., 2006), Monlesi Ice Cave (Leutscher et al. 2007), St. Livres Ice Cave (Leutscher et al., 2005; Stoffel et al., 2009) as well as caves in the Dachstein massif (Audra and Pavuza, 2004). However, it is worth stressing that the ice in the several above mentioned caves started to grow before the LIA in a relatively mild climate period. This may be explained by different microclimatic conditions of those caves representing the static ice caves, called also "cold air traps", which can react in a different way. A robust chronology of cave-ice based on more dating results from more caves along with proper understanding of cave climatic conditions and ice mass balance are needed to unravel this enigma.

\section{CONCLUSIONS}

1) Two generations of ice divided by distinct unconformity were recognized in Lodowa Cave in Ciemniak.

2) The age of younger generation was established by radiocarbon dating of the moths entrapped in the cave-ice. The dating of older moth yielded period 1660-1790 AD and the younger one 1720-1820 AD period. It implies that the ice originated during the Little Ice Age.

3) The distinctive erosion boundary recorded a significant period of ablation which preceded the Little Ice Age probably during the Medieval Warm Period. The older generation of ice is supposed to have originated during cold stage between the Atlantic period and the Medieval Warm Period.

4) The ice volume in the cave was substantially smaller before the Little Ice Age than it is today, despite the clear tendency to melt which has been recognized since 20 s of the last century.

5) Small cave-dwelling creatures like moths are suitable for radiocarbon dating, which allows widening the 
possibility of application of this method to date caveice.

\section{ACKNOWLEDGEMENTS}

The authors wish to thank the colleagues from caving clubs, who assisted them during the field work, as well as Renata Jach and Krzysztof Najdek for their help with some figures. Authorities of the Tatra National Park are kindly acknowledged for providing us permission for researches in the cave. The research was partly supported by Institute of Geological Sciences, Polish Academy of Sciences. The constructive comments of Ján Zelinka and the anonymous reviewer were helpful for improving the manuscript.

\section{REFERENCES}

Alcheitner A, 1995. Zum Alter des Höhleneises in der EisgrubenEishöhle im Sarstein (Oberösterreich) (About the age of cave ice from the Eisgruben-Cave from Sarstein (Oberösterreich)). Die Höhle 46: 1-5 (in German).

Audra P and Pavuza R, 2004. Calcareous Alps, Austria. In: Gunn J, ed, Encyclopedia of Caves and Karst Sciences. New York, Fitzroy Dearborn: 173-175.

Bednarz Z, 1984. The comparison of dendrochronological reconstructions of summer temperatures from the Alps and Tatra Mountains from 1741-1965. Dendrochronologia 2: 63-72.

Bronk Ramsey C, 1995. Radiocarbon Calibration and Analysis of Stratigraphy: The OxCal Program. Radiocarbon 37(2): 425-430.

Bronk Ramsey C, 2001. Development of the radiocarbon calibration program OxCal. Radiocarbon 43: 355-363.

Celejowska P, Głazek J, Jędrysek MO, Kicińska D, Solarczyk S, Szynkiewicz A and Zieliński M, 2007. Badania składu izotopowego tlenu $\mathrm{w}$ warstwach lodowca Jaskini lodowej $\mathrm{w}$ Ciemniaku (Tatry) (The study of oxygen isotope composition in glacier in Lodowa Cave in Ciemniak). In: Stefaniak K, Szelerewicz M and Urban J, eds., Materiaty 41. Sympozjum Speleologicznego, Kletno, Sekcja Speleologiczna PTP, Kraków: 40 (in Polish).

Clausen HB, Vrana K, Bo Hansen S, Larsen IB, Baker J, SiggaardAndersen ML, Sjolte J and Lundholm SC, 2007. Continental ice body in Dobšiná Ice Cave (Slovakia) - part II. - results of chemical and isotopic study. In: Zelínka J, ed., $2^{\text {nd }}$ International Workshop on Ice Caves. Proceedings. Slovak Caves Administration, Liptovský Mikuláš: 29-37.

Czernik J and Goslar T, 2001. Preparation of graphite targets in the Gliwice Radiocarbon Laboratory for AMS ${ }^{14} \mathrm{C}$ dating. Radiocarbon 43: 283-291.

Dietz M and Pir JB, 2009. Distribution and habitat selection of Myotis bechsteinii in Luxemburg: implications for forest management and conservation. Folia Zoologica 58: 327-340.

Ford DC and Williams P, 2007. Karst Hydrogeology and Geomorphology. Wiley, Chichester: 562pp.

Fórizs I, Kern Z, Szánto Z, Nagy B, Palcsu L and Molnár M, 2004. Environmental isotope study on perennial ice in the Focul Viu Ice Cave, Bihor Mountains, Romania. Theoretical and Applied Karstology 17: 61-69.

Gąsiorowski M and Sienkiewicz E, 2010a. The Little Ice Age recorded in sediments of a small dystrophic mountain lake in southern Poland. Journal of Paleolimnology 43(3): 475-487, DOI 10.1007/s10933-009-9344-5.

Gąsiorowski M and Sienkiewicz E, 2010b. 20th century acidification and warming as recorded in two alpine lakes in the Tatra Mountains (South Poland, Europe). Science of the Total Environment 408(5): 1091-1101, DOI 10.1016/j.scitotenv.2009.10.017.

Goslar T, Czernik J and Goslar E, 2004. Low-energy ${ }^{14} \mathrm{C}$ AMS in Poznań Radiocarbon Laboratory. Nuclear Instruments and Methods B 223-224: 5-11, DOI 10.1016/j.nimb.2004.04.005.

Hess MT, 1996. Klimat (Climate). In: Mirek Z, Głowaciński Z, Klimek $\mathrm{K}$ and Piękoś-Mirkowa H, eds, Przyroda Tatrzańskiego Parku Narodowego, Tatrzański Park Narodowy, Zakopane: pp. 53-69 (in Polish, English summary).
Holmlund P, Onac B, Hansson M, Holmgren K, Mörth M, Nyman M and Perşoiu A, 2005. Assessing the palaeoclimate potential of cave glaciers: The example of the Scărişoara Ice Cave (Romania). Geografiska Annaler 87A: 193-201.

Kern Z, Fórizs I, Kázmér M, Nagy B, Szántó Zs, Gál A, Palcscu L and Molnár M, 2004. Late Holocene environmental changes recorded at Ghetarul de la Focul Viu, Bihor Mountains, Romania. Theoretical and Applied Karstology 17: 51-60.

Kotarba A, 2006. The Little Ice Age in the High Tatra Mountains. Studia Quaternaria $23: 47-53$

Kowalski K, 1955. Fauna jaskiń Tatr Polskich (The cave fauna of the Polish Tatra Mountains). Ochrona Przyrody 23: 283-333 (in Polish, English summary).

Lauriol B and Clark DI, 1993. An approach to determine the origin and age of massive ice blockages in two arctic caves. Permafrost and Periglacial Processes 4(1): 77-85, DOI 10.1002/ppp.3430040107.

Lauriol B, Carrier L and Thibaudeau P, 1988. Topoclimatic zones and ice dynamics in the caves of the Nortjhern Yukon, Canadian Arctic 41: 215-220.

Lauriol B, Prévost C, Deschamps É, Cinq-Mars J and Labrecque S, 2001. Faunal and archaeological remains as evidence of climate change in freezing caverns, Yukon territory. Canadian Arctic 54: 135-141.

Luetscher M, Jeannin PY and Haeberli W, 2005. Ice caves as an indicator of winter climate evolution: a case study from the Jura Mountains. Holocene 15(7): 982-993, DOI 10.1191/0959683605hl872ra.

Luetscher M, Bolius D, Schwikowski M, Schotterer U and Smart PL, 2007. Comparison of techniques for dating of subsurface ice from Monlesi Ice Cave, Switzerland. Journal of Glaciology 53(182): 374-384, DOI 10.3189/002214307783258503.

Marshall P and Brown MC, 1974. Ice in Colthard Cave, Alberta. Canadian Journal of Earth Sciences 11: 510-518, DOI 10.1139/e74045 .

Niedźwiedź T, 2004. Rekonstrukcja warunków termicznych lata w Tatrach od 1550 roku (Reconstruction of summer temperature in the Tatra Mountains since 1550). Prace Geograficzne 197: 57-88 (in Polish, English summary).

Pavuza R and Spötl C, 2000. Neue Forschungsergebnisse aus der Hundalm-Eishöhle. (New results of the study from the Hundalm ice cave). Höhlenkundliche Mitteilungen Landesverein für Höhlenkunde Tirol 38: 41-46 (in German).

Rachlewicz G and Szczuciński W, 2004. Seasonal and decadal ice mass balance changes in the ice cave Jaskinia Lodowa w Cieniaku, the Tatra Mountains, Poland. Theoretical and Applied Karstology 17: 11-18.

Racoviţă G and Onac BP, 2000. Scărişoara Glacier Cave. Monographic Study. Cluj-Napoca, Editura Carpathica: 139pp.

Reimer PJ, Baillie MGL, Bard E, Bayliss A, Beck JW, Bertrand C, Blackwell PG, Buck CE, Burr G, Cutler KB, Damon PE, Edwards RL, Fairbanks RG, Friedrich M, Guilderson TP, Hughen KA, Kromer B, McCormac FG, Manning S, Bronk Ramsey C, Reimer RW, Remmele S. Southon JR, Stuiver M, Talamo S, Taylor FW, van der Plicht J and Weyhenmeyer CE, 2004. IntCal04 terrestrial radiocarbon age calibration, $0-26$ cal kyr BP. Radiocarbon 46:1029-1058.

Rygielski W, Siarzewski W and Wieliczko P, 1995. Variability of the ice deposit in Ice Cave on Mount Ciemniak in the West Tatra Mountains. Quaestiones Geographicae 17/18: 55-64.

Schroeder J, 1977. Les formes de glaces des grottes de la Nahanni, Territories du Nord-Ouest, Canada (The ice forms from the Nahanni Cave, the Northwest Territories, Canada). Canadian Journal of Earth Sciences 14(5): 1179-1185, DOI 10.1139/e77108.

Scotter GW and Simmons NM, 1976. Mortality of Dall's sheep within a cave. Journal of Mammalogy 57: 387-389.

Siarzewski W, 1994a. Jaskinia Lodowa w Ciemniaku (Lodowa Cave in Ciemniak). In: Grodzicki J, ed., Jaskinie Tatrzańskiego Parku Narodowego, Tom 5. Jaskinie Waqwozu Kraków. Polskie Towarzystwo Przyjaciół Nauk o Ziemi, Tatrzański Park Narodowy, Warszawa: 142-153 (in Polish).

Siarzewski W, 1994b. Jaskinie Lodowe w Tatrach (Ice caves in the Tatras). In: Grodzicki J, ed., Jaskinie Tatrzańskiego Parku Narodowego, Tom 5. Jaskinie Wạwozu Kraków. Polskie Towarzystwo Przyjaciół Nauk o Ziemi, Tatrzański Park Narodowy, Warszawa: 11-47 (in Polish).

Silvestru E, 1999. Perennial ice in caves in temperature climate and its significance. Theoretical and Applied Karstology 11-12: 83-94. 
Stoffel M, Luetscher M, Bollschweiler M and Schlatter F, 2009. Evidence of NAO control on subsurface ice accumulation in a $1200 \mathrm{yr}$ old cave-ice sequence, St. Livres ice cave, Switzerland. Quaternary Research 72(1): 16-26, DOI 10.1016/j.yqres.2009.03.002.

Yonge CI, 2004. Ice in caves. In: Gunn J, ed., Encyclopedia of Caves and Karst Sciences. New York, Fitzroy Dearborn: 435-437.

Yonge CI and MacDonald W, 1999. The potential of perennial cave ice in isotope palaeoclimatology. Boreas 28(3): 357-362, DOI 10.1111/j.1502-3885.1999.tb00225.x.

Wilson AT, 1998. ${ }^{14} \mathrm{C}$ studies of natural ice. Radiocarbon 40: 953-962.

Wołoszyn BW, 1996. Fauna jaskiń (The fauna of caves). In: Mirek Z,
Głowaciński Z, Klimek K and Piękoś-Mirkowa H, eds., Przyroda Tatrzańskiego Parku Narodowego, Tatrzański Park Narodowy, Zakopane, 525-533 (in Polish, English summary).

Wójcik Z, 1968. Rozwój geomorfologiczny wapiennych obszarów Tatr i innych masywów krasowych Karpat Zachodnich (Geomorphological development of the limstone areas of the Tatra Mts. and other karst massifs in the Western Carpathians). Prace Muzeum Ziemi 13: 3-169 (in Polish, English summary).

Zwoliński S, 1951. Grota lodowa w Tatrach. (An ice cave in the Tatras). Zabytki Przyrody Nieożywionej 4: 19-23. (in Polish, French summary). 